\title{
A autoficção de Grazia Deledda
}

\section{Cosima.}

Deledda, Grazia. Tradução de Maria do Rosário Toschi. Revisão da tradução: Aurora Fomoni Bemardini.

Vinhedo, SP: Horizonte, 2005. 175 p.

Embora as principais obras de referência literária italianas e estrangeiras não dediquem muitas páginas a Grazia Deledda (Nuoro/ Sardenha, 1871 - Roma, 1936) e divirjam na caracterização de sua na rrativa, todos são unânimes em afimar que é uma grande autora do Novecento italiano, podendo ser comparada a escritoras do porte de Jane Austen, Emily Brontë e Virgina Woolf.

Autodidata e uma das poucas mulheres - a única italiana - a obter o Prêmio Nobel de Literatura, em 1926, Grazia Deledda estreou como escritora ainda bastante jovem. Com 17 anos já havia public a do alguns de seus escritos em uma revista de moda, e com o passar dos anos esc reveu diversos romances, em que se encontra "um valor de poesia", para usar as palavras do conhecido crítico Natalino Sapegno. ${ }^{1}$ Dentre os seus romances destacam-se Fior di Sardegna (1892), Elias Portolu (1903), Cenere (1904), Canne al vento (1913), um dos mais conhecidos e traduzidos, e la madre (1920), que mereceu o prefácio de D.H. Lawrence na tradução inglesa.

A Sardenha, suas paisagens, lendas e persona gens são uma consta nte nos esc ritos dessa escritora, que em 1899, a pós seu ma trimônio, se 
transfere para Roma e continua a se dedicar diligentemente à ficção. A a derência à rea lida de, mas também o interesse pelos elementos psicológicos, místicos e supersticiosos caracterizam a sua intensa produção literária. Embora os tra ç os típic os das correntes na tura lista e decadentista estejam bastante presentes na obra de Grazia Deledda, os temas do amor, dor, morte, religião, somados a lugares, figuras, paisagens, são combinados de tal maneira que tomam problemática a a plic ação mecânica de certos rótulos. Não por acaso, a parte ma is famosa da justific ativa do Prêmio Nobel, elaborada pelo júri e lida durante a cerimônia de entrega, dizque Deledda fora escolhida "Pelos seus esc ritos id ea listas inspira d os com c la rid a de plástica das vivências na sua ilha natal, e com profundidade e simpatia pelos problemas humanos em geral".

Devido em parte a o Nobel, Grazia foi muito traduzida, mas no Brasil saíram a penas 0 drama de Regina (1932) e Caniços ao vento (1964) e, recentemente, graças à Editora Horizonte, com sua coleção "Mulheres e Letras", temos à disposição o último livro da escritora sarda.

Cosima, que foi publicado postumamente em 1937, é um romance autobiográfico e narra a história de vida da protagonista, Cosima, da infância à vida adulta, passando pelas vic issitudes cotidianas, do amorà morte, tendo sempre como pano de fundo a Sardenha com suas lendas e personagens, tudo isso a lia do a o seu desabrochar como escritora. Aliás, Cosima pode ser resumido como a história de uma jovem escritora nascida em uma cidade periférica da já isolada Sa rdenha em uma época em que a educação para as mulheres era rara e a carreira literária de uma mulher era mal vista, pois as mulheres deveriam se dedicara o lar, a o casamento, a os filhos. Esse difícil destino é, ao longo do livro, descrito de forma irônica e, às vezes, dramática.

Apesar de a literatura de Deledda muitas vezes situar-se entre o naturalismo de Verga e o decadentismo de D'Annunzio, neste livro, a escritora coloca-se à margem e acima dessas classific ações. Essa autonomia a parece, por exemplo, nas descrições, que são ora de ca ráter rea lista, ora psic ológico, num va ivém encanta dor. Assim, em uma narração impessoal, temos a minuciosa descrição da casa patema:

A casa era simples, mascômoda; dois quartos por andar, grandes, um pouco baixos, com piso e forro de madeira caiados. [...] A porta de entrada, sólida, fechada com uma grossa tranca de ferro [...] Tinha a lareira e um fogão principal marcado por quatro frisos de pedra
[...] Na pia nunca faltava um pequeno caldeirão de cobre cheio de água tirada do poço do quintal [...] (p. 11-13).

E a personagem Cosima é assim retratada:

De baixa estatura, com a cabeça grande, as extremidades minúsculas, com todas as c a rac terístic a sfísic as sed entárias das mulheres de sua raça, talvez de origem líbica, com o mesmo perfil um pouco achatado, os dentes selvagens e o lábio superior muito alongado tinha, porém, uma pele branca aveludada, belíssimos cabelos negros levemente ondulados e os olhos grandes amendoados de um negro doura do e, às vezes, esverdeado, com a pupila grande, exatamente como as mulheres de raca camítica, que um poeta latino chamou "pupila dupla", de um fascínio passional irresistível" (p. 73).

Já quando o narrador em terceira pessoa fala de Santus, um dos irmãos de Cosima, a descrição é ma is de caráter psic ológico:

Quem não andava bem era Santus. A morte do pai, em vez de chamá-lo a si, pareceu afundá-lo cada vez mais no abismo onde, dia após dia, se precipitava. Estudou até chegar ao quarto ano de medicina; mas bebia cada vez mais e já começava a viver alcoolizado [...] Santus é o morto-vivo que anunciava o infemo, sim, mas antes da morte, na própria vida (p. 66-68).

Como se percebe, temos uma Deledda sensível em rela ção a os ma is diferentes a spectos que a vida the impõe, como o sofrimento pelo imão alc oolizado, a morte de sua imã Giovanna, "a ma is bela das cinco imãs" (p. 41), o sofrimento da mãe, a morte de Enza:

Cosima [...] encontrou-a [Enza] insolitamente calma, estendida sobre o leito, palidíssima, com os grandes olhos a medrontados. Não falava, não se movia; mas um cheiro desagradável e quente exalava do leito e quando Cosima, com uma coragem superior à sua idade, procurou descobrir o mistério, deu-se conta que a infeliz Enza jazia em uma poça de sangue negro e fétido. Veio o médico e disse que se tratava de um aborto (p. 71).

Além desses episódios da vida, Cosima tinha ta mbém seus próp rios temores interiores, como o de serfeia, de não encontrarmarido, e também o de não se tomaruma escritora de sucesso.

Com este livro, Deledda nos mostra como é possível superar obstáculos em uma sociedade fechada, patriarcale fortemente religiosa a tra vés de seu firme projeto de se tomar escritora de grande talento. Não poraca so Cosima foi, como 
lembra Aurora Fomoni Bemardini na introdução do livro, durante gerações um dosma is lidospelos jovens de seu país.

\section{Nota}

${ }^{1}$ Sapegno, 1975, p. 719.

\section{Referência bibliográfica}

SAPEGNO, Natalino. Disegno storico della letteratura italiana. Firenze: La Nuovaltália, 1975.

And réia Guerini Universidade Federal de Santa Catarina 